\title{
Magnesium-permeable TRPM6 polymorphisms in patients with meningomyelocele
}

\author{
Mehmet Saraç ${ }^{1 *}$, Ebru Önalan², Ünal Bakal', Tugay Tartar ${ }^{1}$, Mustafa Aydın³, Ayşen Orman ${ }^{3}$, Ahmet Tektemur $^{2}$, \\ Erdal Taşkın³, Fatih Serhat Erol ${ }^{4}$ and Ahmet Kazez ${ }^{1}$
}

\begin{abstract}
Background: To evaluate whether there is an association between single nucleotide polymorphisms in magnesiumpermeable TRPM6 ion channel and development of meningomyelocele (MMC). Therefore, we examined a total of 150 children with MMC, along with age- and gender-matched controls. DNA collected from whole blood was analyzed for the presence of two polymorphisms, rs2274924 (A > G; K1579E; Leu1579Glu) and rs3750425 (G > A; Val1393Ile), in TRPM6. Serum $\mathrm{Mg}^{2+}$ and calcium levels were also examined.

Results: A statistically significant difference in the distribution of rs2274924 genotypes ( $p=0.049)$ was observed between the groups. Decreases in the AA genotype, and increases in the AG heterozygous genotype were also detected in the study group. The distribution of polymorphisms in the rs3750425 genotype and alleles was not statistically different between groups. Serum $\mathrm{Mg}^{2+}$ levels were lower in the GG genotype of rs3750425 compared with the GA and AA genotypes ( $p=0.003$ ).

Conclusions: A statistically significant difference in rs3750425 genotypes was observed between the patients with MMC and the controls, which corresponded to lower serum $\mathrm{Mg}^{2+}$ concentrations in these patients. Taken together, these results suggest that genetic variations in the $\mathrm{Mg}^{2+}$-permeable TRPM6 ion channel may play a role in the etiopathogenesis of MMC during embryonic development.
\end{abstract}

Keywords: Neural tube defect, Spina bifida cystica, Etiopathogenesis, Genetic, Embryogenesis, Development, Human, Children

\section{Background}

Neural tube defects (NTDs) occur during embryogenic period when the neural tube lefts uncovered to close normally and neural tissue exposed to the intrauterine environment. It affects about $0.1-0.4 \%$ in worldwide, $0.3 \%$ in Turkey (Mandiracioğlu et al. 2004; van Rooij et al. 2003) and 2.6/1000 in East Anatolia region of Turkey in live births (Saraç et al. 2007). Meningomyelocele (MMC) is a nonlethal but severely disabling form of NTD (Shutleff and Graaf 2001). Etiology of MMC remains poorly understood, most likely driven by a combination of genetic and

\footnotetext{
*Correspondence: mehmetsarac12@hotmail.com

${ }^{1}$ Department of Pediatric Surgery, Firat University Medical Faculty, 23119 Elazig, Turkey

Full list of author information is available at the end of the article
}

environmental factors (Miao et al. 2016; Au et al. 2010). Genetic factors may contribute up to $70 \%$ of NTD prevalence based on epidemiological evidences to date (Leck 1974; Copp and Greene 2010; Bassuk and Kibar 2009). Maternal health problems, including inadequate nutrition have also been shown to affect neural tube closure through a variety of mechanisms (Copp et al. 2013).

Magnesium $\left(\mathrm{Mg}^{2+}\right)$ is the second most abundant cation in cell and is essential for all stages of life, from the early embryo to adult. Regulation of cellular as well as whole body $\mathrm{Mg}^{2+}$ homeostasis is critical for human health. Although the concentration of $\mathrm{Mg}^{2+}$ in the extracellular environment can vary significantly, the total intracellular $\mathrm{Mg}^{2+}$ concentration is actively maintained within a relatively narrow range $(14-20 \mathrm{mM})$ via tight (Komiya and 
Runnels 2015; Romani 2011). This responsibility largely achives to $\mathrm{Mg}^{2+}$ transporters and ion channels. Transient receptor potential cation channel, subfamily $\mathrm{M}$, member 6 (TRPM6; 602014), located on chromosome 9q21.13, plays a central role in the regulation of $\mathrm{Mg}^{2+}$ homeostasis via absorption and reabsorption of $\mathrm{Mg}^{2+}$ from the small intestines and kidneys, respectively (Song et al. 2009; Hruby et al. 2013; Groenestege et al. 2006; Schlingmann et al. 2005).

Homozygous TRPM6 knockout embryos died by E12.5 and exhibited neural tube closure defects (Walder et al. 2002). The expression pattern of TRPM6 during embryogenesis demonstrated a significant increase at E10, suggesting TRPM6 is also temporally required for early development. Heterozygous TRPM6 knockout mice exhibited mild hypomagnesemia (Walder et al. 2002; Woudenberg-Vrenken et al. 2011). Mutations in TRPM6 occur in the rare autosomal-recessive disease hypomagnesemia with secondary hypocalcemia (HSH) in human (Schlingmann et al. 2002). As indicated in many studies, hypomagnesemia in null mice is sufficient to induce NTDs, as well as developmental disorders of the bones (Walder et al. 2009; Chubanov and Gudermann 2014). Proper $\mathrm{Mg}^{2+}$ levels are also of particular importance to pregnant women, with deficiencies associated with premature birth and intrauterine growth retardation, along with increases in both mortality and morbidity during the embryonic period. Embryotoxic and teratogenic effects of $\mathrm{Mg}^{2+}$ have also been reported in animal models. Lower serum $\mathrm{Mg}^{2+}$ levels are strongly associated with skeletal malformations, osteogenesis imperfecta, and growth retardation of the embryo, as well as dysregulation of fetal temperature and sudden infant death (Hurley et al. 1976; Günther et al. 1981).

The fundamental principles underlying TRPM6 ion channel operation have been described in detail. TRPM7, an ion channel permeable to both $\mathrm{Ca}^{+}$and $\mathrm{Mg}^{2+}$, functions via the formation of heterodimers with TRPM6 (Günther et al. 1981). Single nucleotide polymorphisms (SNPs) of TRPM6 have been associated with diabetes mellitus and serum magnesium level in human (Song et al. 2009; Hruby et al. 2013; Walder et al. 2009). Given these associations, we sought to investigate the role of rs2274924 (A > G; K1579E;Leu1579Glu) ve Rs3750425 ( $\mathrm{G}>\mathrm{A}$ Val1393Ile) polymorphisms in TRPM6 comparing with the frequency of specific genotypes and alleles in patients with MMC and healthy controls and the potential correlation between these SNP variants and serum $\mathrm{Mg}^{2+}$ and calcium concentrations to identify potential functional outcomes associated with disease genotypes.

\section{Methods}

This case-control study was conducted after obtaining approval from the institutional ethics committee (protocol number 31.01.2013/02/12). Oral and written consent were obtained from all families prior to inclusion in this study. A total of 150 patients diagnosed with MMC admitted to the outpatient clinics of neurosurgery, pediatric surgery, and pediatrics were enrolled in this study. An additional 150 patients admitted to the pediatric surgery outpatient clinic with no evidence of abnormal sacral spine examination findings were used as a control group. The demographic characteristics and clinical history of each patient were investigated in detail. Evidence of consanguineous marriage between parents or earlier generations was also noted. Due to the possibility of teratogenic effects, maternal use of any drug during the periconceptional period was recorded. Serum calcium and $\mathrm{Mg}^{2+}$ levels were assessed using a colorimetric assay.

\section{Isolation of DNA}

DNA isolation was performed using the Promega Wiz$\operatorname{ard}^{\circledR}$ Genomic DNA Isolation Kit according to the manufacturer's instructions. The DNA concentration was measured using a MaestroNano ${ }^{\circledR}$ (MaestroNanodrop; Maestrogen, USA), and diluted to 1-10 ng.

\section{Genotyping using TaqMan ${ }^{\circledR}$ probes}

SNPs of rs2274924 (A > G; K1579E;Leu1579Glu) and rs3750425 (G > A; Val1393Ile) in TRPM6 were analyzed using $\operatorname{TaqMan}^{\circledR}$ probes in combination with an ABI 7500 Fast Real-Time PCR System (Applied Biosystems, Foster City, CA, USA). The genomic sequence of rs2274924 was assessed using the probe AGTCCTTGAGTATTCTTCTTTTTCT[C/ T]TGACAGTCTCCTGTCTTTGGTTAGC (Assay ID: C_16183233_20). Polymorphism at this nucleotide confers an AAG to GAG substitution, resulting in a leucine to glutamic acid substitution at residue 1579. For genotyping, the kit used FAM and VIC florescent dyes for the A and $\mathrm{G}$ alleles, respectively, as forward and reverse primers. The genomic sequence of rs3750425 was assessed using the probe TCCACTGATGCCCAGTCAGAGACAA[C/ T]TGGGGTCTGCCCAGTCAGATGAACA (Assay ID: C_25943493_20). Polymorphism at this nucleotide confers an ATT to GAG substitution, resulting in a valine to isoleucine substitution at residue 1393. For genotyping, the kit used FAM and VIC florescent dyes for the A and $\mathrm{G}$ alleles, respectively, as forward and reverse primers. All polymerase chain reaction $(\mathrm{PCR})$ reaction mixtures were prepared on ice.

From each sample, we combined $2.5 \mu \mathrm{L}$ DNA with $7.5 \mu \mathrm{L}$ PCR reaction mixture for a final volume of $10 \mu \mathrm{L}$. 
Plates were then covered with optical film, centrifuged, and analyzed using a 7500 Fast Real-Time PCR System for 40 cycles. The device software was used to identify homozygous mutant, heterozygous, and homozygous normal genotypes for each allele.

\section{Statistical analysis}

Data were analyzed using the IBM Statistical Package for the Social Sciences v. 21 (SPSS Inc., Chicago, IL, USA). Relationships between parameters were assessed using Pearson's correlation analysis. Distributions of genotype and allele frequency were analyzed using a Chi square test. The Mann-Whitney $U$ test was used to evaluate differences between groups. Data were expressed as the mean \pm standard deviation. A $p$ value $<0.05$ was considered statistically significant.

\section{Results}

The study group $(\mathrm{n}=150)$ consisted of 60 female $(40 \%)$ and $90(60 \%)$ male patients. The mean age of the study group was $3.1 \pm 3.22$ years (range 1 month-18 years). The mean age of the mothers was $28.15 \pm 4.71$ years (range 19-44 years). A detailed list of demographic, clinical, and laboratory findings are presented in Table 1.

No significant differences in genotype or allele distributions of TRPM6 rs3750425 polymorphisms were evident between the groups (Table 2). In contrast, a statistically significant difference was observed between the study and control groups in terms of the distribution of the rs2274924 genotype $(\mathrm{p}=0.049)$. Prevalence of the AA genotype was markedly decreased in patients with MMC, while the heterozygous AG genotype was increased. However, no significant difference in the distribution of rs2274924 alleles was observed between the groups (Table 2).

Within the study group, we observed a statistically significant difference in serum $\mathrm{Mg}^{2+}$ levels associated with

Table 1 Demographic, clinical, and laboratory findings of each group

\begin{tabular}{lll}
\hline & Study group & Control group \\
\hline Age (years) & $3.1 \pm 3.22$ & $9.7 \pm 2.21$ \\
Female/male & $60 / 90$ & $75 / 75$ \\
$\begin{array}{l}\text { History of another baby } \\
\quad \text { with MMC in the family }\end{array}$ & $18(11.9 \%)$ & - \\
Consanguinity between parents & $41(27.3 \%)$ & $15(10 \%)$ \\
History of another baby with & $32(21.3 \%)$ & $10(6.6 \%)$ \\
$\quad$ a congenital anomaly in the family & & \\
$\begin{array}{l}\text { Drug use during pregnancy } \\
\text { Calcium (mg/dL) }\end{array}$ & $25(16.6 \%)$ & $15(10 \%)$ \\
Mg $^{2+}$ (mg/dL) & $9.09 \pm 1.24$ & $10.0 \pm 1.25$ \\
\hline
\end{tabular}

MMC Meningomyelocele rs3750425 genotypes but not for rs2274924 genotype. Serum $\mathrm{Mg}^{2+}$ levels were significantly lower in patients harboring the rs3750425 GG genotype relative to those possessing either the GA or AA genotypes $(\mathrm{p}=0.003$; Table 3). No differences were observed in relation to rs2274924 genotypes.

\section{Discussion}

Our statistical finding focused on two coding SNPs in TRPM6 in NTD patients. TRPM6 polymorphism may contribute to different ways the NTD development, such as regulating osteogenesis during embryonic development, effecting the maternal serum magnesium level in pregnant women and changing in the expression level under the influence of estrogen hormone during pregnancy.

A limited number of studies have investigated the potential links between TRPM6 variations and human disease. In our study population, approximately $31.5 \%$ are heterozygous for the rare $G$ allele of rs2274924 and 22 \% heterozygous for the allele $A$ of rs3750425. The HapMap studies were shown that population frequencies are $0.07-0.21$ for the rs3750425 $A$ allele (1393 Ile) and 0.150.36 for the rs2274924 $G$ allele (1584Glu) in four ethnic groups (Walder et al. 2009). Song et al. (2009) provide suggestive evidence that two common non-synonymous TRPM6 coding region variants, Ile1393Val (rs3750425) and Lys1584Glu (rs2274924) polymorphisms, might confer susceptibility to type 2 diabetes in women with low magnesium intake. However, a follow-up study of Romero et al. (2010), Shuen et al. (2009) failed to duplicate these results for rs3750425 and rs2274924. A significant association was observed between common variants of TRPM6 and hypomagnesemia (Hruby et al. 2013; Meyer et al. 2010), with a specific $T$ allele of rs11144134 in TRPM6 associated with higher femoral neck and lumbar spine BMD (Meyer et al. 2010). Magnesium-deficiency has been linked to osteoporosis and low BMD in observational and animal studies (Alexander et al. 2008). Disorders in osteogenesis responsible from inhibition of bone matrix mineralization (Semczuk and SemczukSikora 2001; Durlach 2004; Takaya et al. 2006). The transcripts of canonical TRPM6 channel were also revealed in human MG-63, SaOS and U2 OS osteoblast cell lines (Abed et al. 2009). These observations show that TRPM6 may important the control of bone homeostasis during embryonic and adulthood. Polymorphic amino acids for two polymorphisms investigated in present study are located between the coiled region and kinase near the C-terminal (Schlingmann et al. 2004). Although these amino acid changes in coiled region of TRPM6 protein are improbable responsible for direct regulation of transmembrane structures and kinase activity, they may alter 
Table 2 Frequencies of the genotypes and alleles of rs3750425 and rs2274924 polymorphisms in the transient receptor potential cation channel, subfamily M, member 6 (TRPM6) gene

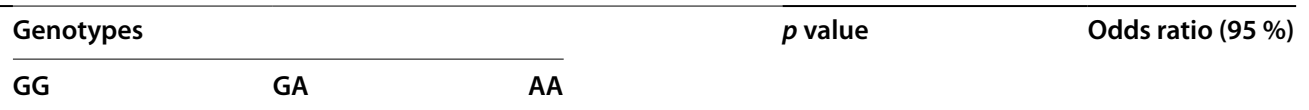

\begin{tabular}{|c|c|c|c|c|c|}
\hline \multicolumn{6}{|c|}{ rs3750425 Polymorphism groups } \\
\hline Study group & 94 & 53 & 3 & 0.14 & $1.45(0.88-2.39)$ \\
\hline \multirow[t]{3}{*}{ Control group } & 103 & 40 & 7 & & \\
\hline & \multicolumn{2}{|c|}{ Alleles } & & & \\
\hline & G & A & & & \\
\hline Study group & 241 & 59 & 0.68 & $1.11(0.74-1.67)$ & \\
\hline \multirow[t]{3}{*}{ Control group } & 246 & 54 & & & \\
\hline & \multicolumn{3}{|c|}{ Genotypes } & & \\
\hline & AA & AG & GG & & \\
\hline \multicolumn{6}{|c|}{ rs2274924 Polymorphism groups } \\
\hline Study group & 71 & 66 & 13 & 0.049 & $1.84(1.13-3)$ \\
\hline \multirow[t]{3}{*}{ Control group } & 91 & 46 & 13 & & \\
\hline & \multicolumn{2}{|c|}{ Alleles } & & & \\
\hline & A & G & & & \\
\hline Study group & 214 & 86 & 0.22 & $1.27(0.88-1.83)$ & \\
\hline Control group & 228 & 72 & & & \\
\hline
\end{tabular}

$G G$ wild type, $G A$ heterozygous, $A A$ polymorphic allele, $A A$ wild type, $A G$ heterozygous, $G G$ polymorphic allele

Table 3 Mean serum $\mathrm{Mg}^{2+}$ and $\mathrm{Ca}^{+}$levels in patients with meningomyelocele (MMC) according to their genotype

\begin{tabular}{llllll}
\hline Polymorphism & \multicolumn{2}{l}{ Calcium } & $\boldsymbol{p}$ value & $\mathbf{M g}^{\mathbf{2 +}}$ & $\boldsymbol{p}$ value \\
\hline rs3750425 & GG & $9.2 \pm 1.20$ & 0.48 & $1.51 \pm 0.31$ & 0.003 \\
& GA & $9.0 \pm 1.21$ & & $2.0 \pm 0.34$ & \\
& AA & $9.5 \pm 1.18$ & & $2.1 \pm 0.38$ & \\
rs2274924 & AA & $9.35 \pm 1.17$ & 0.33 & $1.80 \pm 0.41$ & 0.37 \\
& AG & $9.02 \pm 1.15$ & & $1.82 \pm 0.48$ & \\
& GG & $9.30 \pm 1.2$ & & $1.81 \pm 0.42$ & \\
& & & & &
\end{tabular}

protein conformation and thus decrease TRPM6 channel activity.

$\mathrm{Mg}^{2+}$ deficiency causes or contributes to some abnormalities during embrionic development in human and rats. The decreased maternal $\mathrm{Mg}^{2+}$ intake because of inadequate nutrition and embryonic genetic defects might be responsible from $\mathrm{Mg}^{2+}$ deficiency. A maternal $\mathrm{Mg}^{2+}$ intake below $378 \mathrm{mg} /$ day has been associated with a twofold to threefold higher risk for the neural tube defect, spina bifida in offspring, suggesting a pivotal role for $\mathrm{Mg}^{2+}$ not just in growth but in morphogenesis as well (Groenen et al. 2004). A decrease in basal $\left[\mathrm{Mg}^{2+}\right] \mathrm{i}$ from cord blood platelets is associated with small for gestational age (SGA) babies in humans (Venu et al. 2008). Oral $\mathrm{Mg}^{2+}$ supplementation given before the 25th week of gestation is also associated with a lower frequency of preterm births, a lower frequency of low birth weight, and fewer SGA infants compared with placebo (Makrides and Crowther 2001). Pups of pregnant females fed a $\mathrm{Mg}^{2+}$ deficient diet demonstrated an increased incidence of resorptions, gross malformation, growth retardation, abnormal fat metabolism, insulin resistance and diabetes (Hurley et al. 1976; Venu et al. 2008). Despite these apparent links between maternal serum $\mathrm{Mg}^{2+}$ levels and some embryonic and fetal anomalies, no correlation was found between maternal or neonatal serum $\mathrm{Mg}^{2+}$ levels and MMC (Golalipour and Mansourian 2010). These observations are broadly consistent with the results presented here, with no significantly different neonatal serum $\mathrm{Mg}^{2+}$ or $\mathrm{Ca}^{+}$levels evident between the groups, although lower serum $\mathrm{Mg}^{2+}$ levels were detected in patients with GG genotypes in rs3750425 compared with either the GA or AA variants. As $\mathrm{Mg}^{2+}$ homeostasis in the embryo is critically dependent on the maternal blood supply, a lack of genetic and biochemical analysis of maternal serum samples to assess whether $\mathrm{Mg}^{2+}$ homeostasis was altered during prenatal development was the main limitation of our study.

Recent studies have continued to add to the growing number of $\mathrm{Mg}^{2+}$ transporters and ion channels 
involved in $\mathrm{Mg}^{2+}$ homeostasis during embryogenesis. The expression pattern of TRPM6 during embryogenesis demonstrated a significant increase at E10, suggesting TRPM6 is also temporally required for early development. Heterozygous TRPM6 knockout mice exhibited mild hypomagnesemia (Walder et al. 2002; WoudenbergVrenken et al. 2011). Interestingly, in one of the studies dams fed with a high $\mathrm{Mg}^{2+}$ diet slightly suppressed the embryonic lethality caused by knockout of TRPM6, suggesting that embryonic lethality may in part be due to $\mathrm{Mg}^{2+}$ deficiency. However, in the second study by Woudenberg-Vreken et al. (2011) a high $\mathrm{Mg}^{2+}$ diet failed to rescue the lethality caused by homozygous deletion of TRPM6. Rare mutations or polymorphic variants in TRPM6, including amino acid substitutions that prevent its heterooligomerization with TRPM7 or changing channel activity, may cause the imbalance in intracellular magnesium level and likely to contribute the abnormal bone development during embryogenesis.

Recent studies have shown that estrogen directly increases the transcription of TRPM6, as well as its activity (Cao et al. 2009); this effect is of particular importance during pregnancy, due to the marked increase in maternal estrogen levels. As $90 \%$ of maternal estriol consists of fetal precursors, these effects take on added significance (Buster et al. 1976). Given the strong evidence that estrogen influences TRPM6 synthesis during pregnancy, this gene is likely to play an important role in the regulation of $\mathrm{Mg}^{2+}$ homeostasis in both the mother and fetus. Genetic variations in TRPM6 may therefore affect intracellular $\mathrm{Mg}^{2+}$ levels during embryonic development, with significant implications for fetal development.

Several limitations in present study must be completed with further consideration. First, our study had relatively small sample size, however, consistency with laboratory findings makes our results acceptable. Second, population's etnic diversity may be a concern but imposible to clarify our findings, because our populations are racially homogeneous, all participant lived in Elazig region. Third, althought serum magnesium may be a good indicator for heavy magnesium deficiency, we didn't performed the measures of extracellular or intracellular magnesium status and the patch clamp experiment to display the effect on channel activity of studying polymorphic variant in TRPM6 gene.

Clinical data show that sufficient magnesium intake can partially compensate for the severe magnesium deficiency caused by genetic defect in the TRPM6 gene (Altınclk et al. 2016). High magnesium concentrations in intestinal tracts may overcome the genetic defects of magnesium absorption and independently increase magnesium absorption via the other pathways. Inadequating of dietary magnesium intake, the function of TRPM6 in active intestinal magnesium absorption and renal reabsorption happen very important. Based on these observations, we strongly recommend checking serum $\mathrm{Mg}^{2+}$ values of babies born with MMC. Further studies performed on a large number of patients will be necessary to confirm these findings, as well as clarify the etiology of MMC, particularly in the context of $\mathrm{Mg}^{2+}$ homeostasis.

\section{Authors' contributions}

MS drafted and wrote the manuscript. EÖ carried out the genetic studies, participated in the sequence alignment and performed the statistical analysis. ÜB provided related articles and helped the writing of manuscript. TT participated in the design of the study and transferred blood samples to laboratory. AT participated in the genetic studies and sequence alignment. MA conceived of the study, and participated in its design and coordination and helped to draft the manuscript. AO cared of the patients and collected blood samples from the patients. ET gave care to the patients and redacted the English. FSE performed surgery to the patients. AK supervised the study throughout from planning to writing of the paper. All authors read and approved the final manuscript.

\section{Author details}

${ }^{1}$ Department of Pediatric Surgery, Firat University Medical Faculty,

23119 Elazig, Turkey. ${ }^{2}$ Department of Medical Biology, Firat University Medical Faculty, Elazig, Turkey. ${ }^{3}$ Department of Neonatology, Firat University Medical Faculty, Elazig, Turkey. ${ }^{4}$ Department of Neurosurgery, Firat University Medical Faculty, Elazig, Turkey.

\section{Acknowledgements}

This study was supported by The Scientific and Technological Research Council of Turkey (TUBITAK) within the scope of 1002 rapid support projects (Project No. 114S749),

\section{Competing interests}

The authors declare that they have no competing interests.

Received: 21 June 2016 Accepted: 26 September 2016

Published online: 03 October 2016

\section{References}

Abed E, Labelle D, Martineau C, Loghin A, Moreau R (2009) Expression of transient receptor potential (TRP) channels in human and murine osteoblastlike cells. Mol Membr Biol 26(3):146-158

Alexander RT, Hoenderop JG, Bindels RJ (2008) Molecular determinants of magnesium homeostasis: insights from human disease. J Am Soc Nephrol 19(8):1451-1458

Altıncık A, Schlingmann KP, Tosun MS (2016) A novel homozygous mutation in the transient receptor potential melastatin 6 gene: a case report. J Clin Res Pediatr Endocrinol 8(1):101-104

Au KS, Ashley-Koch A, Northrup H (2010) Epidemiologic and genetic aspects of spina bifida and other neural tube defects. Dev Disabil Res Rev 16(1):6-15

Bassuk AG, Kibar Z (2009) Genetic basis of neural tube defects. Semin Pediatr Neurol 16(3):101-110

Buster JE, Sakakini J Jr, Killam AP, Scragg WH (1976) Serum unconjugated estriol levels in the third trimester and their relationship to gestational age. Am J Obstet Gynecol 125(5):672-676

Cao G, van der Wijst J, van der Kemp A, van Zeeland F, Bindels RJ, Hoenderop JG (2009) Regulation of the epithelial $\mathrm{Mg}^{2+}$ channel TRPM6 by estrogen and the associated repressor protein of estrogen receptor activity (REA). J Biol Chem 284(22):14788-14795

Chubanov V, Gudermann T (2014) TRPM6. Handb Exp Pharmacol 222:503-520

Copp AJ, Greene ND (2010) Genetics and development of neural tube defects. J Pathol 220(2):217-230

Copp AJ, Stanier P, Greene ND (2013) Neural tube defects: recent advances, unsolved questions, and controversies. Lancet Neurol 12(8):799-810 
Durlach J (2004) New data on the importance of gestational Mg deficiency. J Am Coll Nutr 23(6):694-700

Golalipour MJ, Mansourian AR (2010) Maternal and neonatal serum $\mathrm{Mg}^{2+}$ concentrations in neural tube defects pregnancies in Gorgan (North of Iran)—a case control study. J Clin Diagn Res 4:2817-2821

Groenen PM, van Rooij IA, Peer PG, Ocké MC, Zielhuis GA, Steegers-Theunissen RP (2004) Low maternal dietary intakes of iron, magnesium, and niacin are associated with spina bifida in the offspring. J Nutr 134(6):1516-1522

Groenestege WM, Hoenderop JG, van den Heuvel L, Knoers N, Bindels RJ (2006) The epithelial $\mathrm{Mg}^{2+}$ channel transient receptor potential melastatin 6 is regulated by dietary $\mathrm{Mg}^{2+}$ content and estrogens. J Am Soc Nephrol 17(4):1035-1043

Günther T, Ising H, Mohr-Nawroth F, Chahoud I, Merker HJ (1981) Embryotoxic effects of $\mathrm{Mg}^{2+}$ deficiency and stress on rats and mice. Teratology 24(2):225-233

Hruby A, Ngwa JS, Renström F, Wojczynski MK, Ganna A, Hallmans G, Houston DK, Jacques PF, Kanoni S, Lehtimäki T, Lemaitre RN, Manichaikul A, North KE, Ntalla I, Sonestedt E, Tanaka T, van Rooij FJ, Bandinelli S, Djoussé L, Grigoriou E, Johansson I, Lohman KK, Pankow JS, Raitakari OT, Riserus U, Yannakoulia M, Zillikens MC, Hassanali N, Liu Y, Mozaffarian D, Papoutsakis C, Syvänen AC, Uitterlinden AG, Viikari J, Groves CJ, Hofman A, Lind L, McCarthy MI, Mikkilä V, Mukamal K, Franco OH, Borecki IB, Cupples LA, Dedoussis GV, Ferrucci L, Hu FB, Ingelsson E, Kähönen M, Kao WH, Kritchevsky SB, Orho-Melander M, Prokopenko I, Rotter JI, Siscovick DS, Witteman JC, Franks PW, Meigs JB, McKeown NM, Nettleton JA (2013) Higher $\mathrm{Mg}^{2+}$ intake is associated with lower fasting glucose and insulin, with no evidence of interaction with select genetic loci, in a meta-analysis of 15 CHARGE Consortium Studies. J Nutr 143(3):345-353

Hurley LS, Cosens G, Theriault LL (1976) Teratogenic effects of $\mathrm{Mg}^{2+}$ deficiency in rats. J Nutr 106(9):1254-1260

Komiya Y, Runnels LW (2015) TRPM channels and magnesium in early embryonic development. Int J Dev Biol 59(7-9):281-288

Leck I (1974) Causation of neural tube defects: clues from epidemiology. $\mathrm{Br}$ Med Bull 30(2):158-163

Makrides M, Crowther CA (2001) Magnesium supplementation in pregnancy. Cochrane Database Syst Rev (4):CD000937. doi:10.1002/14651858. CD000937.pub2

Mandiracioğlu A, Ulman I, Lüleci E, Ulman C (2004) The incidence and risk factors of neural tube defects in Izmir, Turkey: a nested case-control study. Turk J Pediatr 46(3):214-220

Meyer TE, Verwoert GC, Hwang SJ, Glazer NL, Smith AV, van Rooij FJ, Ehret GB, Boerwinkle E, Felix JF, Leak TS, Harris TB, Yang Q, Dehghan A, Aspelund T, Katz R, Homuth G, Kocher T, Rettig R, Ried JS, Gieger C, Prucha H, Pfeufer A, Meitinger T, Coresh J, Hofman A, Sarnak MJ, Chen YD, Uitterlinden AG, Chakravarti A, Psaty BM, van Duijn CM, Kao WH, Witteman JC, Gudnason V, Siscovick DS, Fox CS, Köttgen A (2010) Genetic factors for osteoporosis consortium; meta-analysis of glucose and insulin related traits consortium. Genome-wide association studies of serum magnesium, potassium, and sodium concentrations identify six Loci influencing serum magnesium levels. PLoS Genet 6(8). doi:10.1371/journal.pgen.1001045

Miao C, Jiang Q, Li H, Zhang Q, Bai B, Bao Y, Zhang T (2016) Mutations in the motile cilia gene dnaaf1 are associated with neural tube defects in humans. G3 (Bethesda). doi:10.1534/g3.116.033696

Romani AM (2011) Cellular magnesium homeostasis. Arch Biochem Biophys 512(1):1-23

Romero JR, Castonguay AJ, Barton NS, Germer S, Martin M, Zee RY (2010) Gene variation of the transient receptor potential cation channel, subfamily M, members 6 (TRPM6) and 7 (TRPM7), and type 2 diabetes mellitus: a casecontrol study. Transl Res 156(4):235-241

Saraç M, Özel ŞK, Kazez A (2007) Spina bifida: current situation in Eastern Anatolia. Çocuk Cerrahisi Dergisi 21(3):116-119
Schlingmann KP, Weber S, Peters M, Niemann Nejsum L, Vitzthum H, Klingel K, Kratz M, Haddad E, Ristoff E, Dinour D, Syrrou M, Nielsen S, Sassen M, Waldegger S, Seyberth HW, Konrad M (2002) Hypomagnesemia with secondary hypocalcemia is caused by mutations in TRPM6, a new member of the TRPM gene family. Nat Genet 31(2):166-170

Schlingmann KP, Konrad M, Seyberth HW (2004) Genetics of hereditary disorders of magnesium homeostasis. Pediatr Nephrol 19(1):13-25

Schlingmann KP, Sassen MC, Weber S, Pechmann U, Kusch K, Pelken L, Lotan D, Syrrou M, Prebble JJ, Cole DE, Metzger DL, Rahman S, Tajima T, Shu SG, Waldegger S, Seyberth HW, Konrad M (2005) Novel TRPM6 mutations in 21 families with primary hypomagnesemia and secondary hypocalcemia. J Am Soc Nephrol 16(10):3061-3069

Semczuk M, Semczuk-Sikora A (2001) New data on toxic metal intoxication $(\mathrm{Cd}, \mathrm{Pb}$, and $\mathrm{Hg}$ in particular) and $\mathrm{Mg}$ status during pregnancy. Med Sci Monit 7(2):332-340

Shuen AY, Wong BY, Wei C, Liu Z, Li M, Cole DE (2009) Genetic determinants of extracellular $\mathrm{Mg}^{2+}$ concentration: analysis of multiple candidate genes, and evidence for association with the estrogen receptor alpha (ESR1) locus. Clin Chim Acta 409(1-2):28-32

Shutleff DB, Graaf WD (2001) Overview of clinical issues in the management of myelomeningocele. In: Sarwark JF, Lubicky J (eds) Caring for the child with spina bifida, 1st edn. American Academy of Orthopedic Surgeons, Illinois

Song Y, Hsu YH, Niu T, Manson JE, Buring JE, Liu S (2009) Common genetic variants of the ion channel transient receptor potential membrane melastatin 6 and 7 (TRPM6 and TRPM7), Mg ${ }^{2+}$ intake, and risk of type 2 diabetes in women. BMC Med Genet 10:4

Takaya J, Yamato F, Kaneko K (2006) Possible relationship between low birth weight and $\mathrm{Mg}^{2+}$ status: from the standpoint of "fetal origin" hypothesis. Magnes Res 19(1):63-69

van Rooij IA, Vermeij-Keers C, Kluijtmans LA, Ocké MC, Zielhuis GA, GoorhuisBrouwer SM, van der Biezen JJ, Kuijpers-Jagtman AM, Steegers-Theunissen RP (2003) Does the interaction between maternal folate intake and the methylenetetrahydrofolate reductase polymorphisms affect the risk of cleft lip with or without cleft palate? Am J Epidemiol 157(7):583-591

Venu L, Padmavathi IJ, Kishore YD, Bhanu NV, Rao KR, Sainath PB, Ganeshan M, Raghunath M (2008) Long-term effects of maternal magnesium restriction on adiposity and insulin resistance in rat pups. Obesity (Silver Spring) 16(6):1270-1276

Walder RY, Landau D, Meyer P, Shalev H, Tsolia M, Borochowitz Z, Boettger MB, Beck GE, Englehardt RK, Carmi R, Sheffield VC (2002) Mutation of TRPM6 causes familial hypomagnesemia with secondary hypocalcemia. Nat Genet 31(2):171-174

Walder RY, Yang B, Stokes JB, Kirby PA, Cao X, Shi P, Searby CC, Husted RF, Sheffield VC (2009) Mice defective in Trpm6 show embryonic mortality and neural tube defects. Hum Mol Genet 18(22):4367-4375

Woudenberg-Vrenken TE, Sukinta A, van der Kemp AW, Bindels RJ, Hoenderop JG (2011) Transient receptor potential melastatin 6 knockout mice are lethal whereas heterozygous deletion results in mild hypomagnesemia. Nephron Physiol 117(2):p11-p19

\section{Submit your manuscript to a SpringerOpen ${ }^{\circ}$ journal and benefit from:}

- Convenient online submission

- Rigorous peer review

- Immediate publication on acceptance

- Open access: articles freely available online

- High visibility within the field

- Retaining the copyright to your article

Submit your next manuscript at springeropen.com 